The emergence of venture firms themselves reflects the process of minimizing the financial risk of investors, that is, venture firms are those structures whose concept of creation includes the idea of minimizing risk.

A venture capital firm can distribute funds between a few different business projects. Thanks to this, the unsuccessful result of one or more investments allowed in advance will be compensated at the expense of other, more successful investments.

In addition to reducing the level of risk, each of the venture investors of customer projects contributes to creating a synergy effect from combining special knowledge, business connections and management experience, and so on.

Venture entrepreneurship in our country is at an early stage, but it has certain growth prospects to play the role of a catalyst for the further development of innovative small businesses.

УДК 336.719:336.01:339.137.2

DOI: 10.35340/2308-104X.2020.89-4-03

\section{МЕТОДОЛОГІЧНЕ ПІДГРУНТЯ ДОСЛІДЖЕННЯ РОЗВИТКУ БАНКІВСЬКОГО СЕКТОРУ НАЦІОНАЛЬНОЇ ЕКОНОМІКИ}

\section{METHODOLOGICAL BASIS OF THE RESEARCH OF THE BANKING SECTOR DEVELOPMENT OF THE NATIONAL ECONOMY}

\author{
ДЯТЛОВА Ю. В., \\ доктор економічних наук, доцент, \\ завідувач кафедри фінансів та \\ обліку, \\ Донецький державний \\ університет управління
}

\author{
DIATLOVA Yu., \\ Doctor of Science in Economics, \\ Associate Professor, \\ Head of the Department of Finance \\ and Accounting, Donetsk State \\ University of Management
}

Сформовано методологічне підгрунтя дослідження розвитку банківського сектору країни за умов відкритості фінансового ринку для іноземних банків. Визначено наукові підходи до дослідження прочесів розвитку (поведінковий, структурний, функціональний, комплексний). Виокремлено постулати теорії конкурентної інтерналізації, щзо виходить з теорій конкуренції, конкурентних переваг, міжнародного руху капіталів. Висунуто гіпотези щцодо розвитку банківського сектору. Запропоновано напрями їх методичного обтрунтування.

Ключові слова: банківський сектор, дослідження розвитку, методологічне підгрунтя, наукові підходи, постулати теорії, гіпотези, напрями методичного обтрунтування.

Сформировань методологические основы исследования развития банковского сектора страны в условиях открытости финансового рынка для иностранных банков. Определены научные подходы к исследованию 
процессов развития (поведенческий, структурный, функциональный, комплексный). Выделены постулаты теории конкурентной интернализации, вытекающей из теорий конкуренции, конкурентных преимуществ, международного движения капиталов. Bыдвинутьл гипотезы по развитию банковского сектора. Предложены направления их методического обоснования.

Ключевые слова: банковский сектор, исследования развития, методологические основы, научные подходы, постулаты теории, гипотезы, направления методического обоснования.

The methodological basis for the study of the development of the banking sector of the country in terms of openness of the financial market for foreign banks was formed. he scientific approaches to the study of development processes (behavioral, structural, functional, integrated) were defined. The postulates of the theory of competitive internalization, arising from the theories of competition, competitive advantages, international movement of capital. Hypotheses on the development of the banking sector are put forward. The directions of their methodological substantiation are offered.

Key words: banking sector, development research, methodological basis, scientific approaches, theory postulates, hypotheses, directions of methodical substantiation.

Постановка проблеми. Банківський сектор є одним із секторів економіки, який найбільше зазнав впливу глобалізації та став значно інтерналізованим. Ініціація концепції конкурентної інтерналізації у банківському секторі відбулася через певні фактори та причини [1]. Однією з причин є лібералізація діяльності фінансових установ. Крім того, розвиток комунікаційних та інших технологій також сприяв тому, що тепер регулюючим банкам у країні-постачальнику капіталу легше контролювати свої банки і свій капітал в іноземній економіці. Інші фактори також є суттєвими фактами збільшення інтерналізації, наприклад, частки активів іноземних банків на банківському ринку приймаючих країн 3 економікою, що розвивається [2]. Посилення глобалізації та інтерналізації змушує країни застосовувати різні стратегії для підтримки своїх внутрішніх установ у цьому глобалізованому сценарії, що потребує певного методологічного підгрунтя.

Аналіз останніх досліджень і публікацій. За останні роки як зарубіжна, так і вітчизняна література поповнилися значною кількістю змістовних досліджень банківського сектору економіки, які з точки зору теорії, методології та практики піддані аналізу [3]. Віддаючи належне розробкам вчених, слід зазначити, що на сьогодні не сформовано деталізованого пояснення умов розвитку банківської системи та комерційного сектору приймаючої країни в конкурентному середовищі з банками іноземних фінансових груп, що актуалізує методологічні розробки.

Mema cmammi полягає в формуванні методологічного підгрунтя дослідження розвитку банківського сектору національної економіки

Виклад основного матеріалу дослідження. В основу теоретичного підходу до розвитку банківського сектору в умовах конкурентної інтерналізації покладено теорії конкуренції, конкурентних переваг, міжнародного руху капіталу, основні положення яких визначені у працях засновників [4; 5; 6] і розвинуті послідовниками. Положення цих теорій стосуються здебільшого 
виробничої та торгівельної сфер, аргументувати їх інтерпретацію щодо банківського сектору можна тим, що функціонування банків $є$ тотожним функціонуванню суб'єктів підприємництва в умовах конкуренції.

Еволюція теорії конкуренції виявляє наявність низки наукових думок щодо іiі ролі у національній економіці, на галузевих ринках, факторів та умов конкурентоспроможності та формування конкурентних переваг, методів конкурентної боротьби. Проте, існують певні ознаки конкуренції, які у теорії визнаються безперечними, аксіоматичними. Зокрема, вважаємо погодитися із Л. Юрчишиною, яка серед них виділяє: наявність суб'єктів конкурентної взаємодії; прагнення до успіху в конкурентній боротьбі; результат, що виявляє позиції переможця і переможеного; наявність конкурентних мотивів та інші [7]. Т. Литвиненко також вказує на базову складову сутності конкуренції змагальність, або суперництво, виокремлюючи також ознаку наявності особистого мотиву, зацікавленості в досягненні результату суб'єктів підприємництва [8].

Слід відзначити й наявність у сучасній економічній науці трьох підходів до погляду на конкуренцію: поведінковий, який розглядає аксіоматичні ознаки конкуренції - формування поведінки суб'єктів підприємництва під впливом зіткнення, боротьби, змагання із конкурентами за реалізацію своїх інтересів; структурний, який передбачає оцінку впливу умов і факторів конкурентного середовища, що визначають розвиток суб'єктів підприємництва; функціональний, який акцентує увагу на наслідках конкуренції для економіки в цілому та їі сфер і секторів тощо [7-9]. Вважаємо, що аксіоматичне ядро теорії конкуренції полягає в межах лише поведінкового підходу i, відповідно, може трактуватися як вмотивовані дії суб'єктів підприємництва на конкурентному ринку у оперуванні ціною товару/послуги, якістю, інноваціями 3 метою перемоги у конкурентній боротьбі.

Особливості банківської діяльності (як то: наявність жорстких макропруденційних вимог, товар у виді банківських послуг, відповідні їм інструменти) обумовлюють формування постулатів розвитку банківського сектору з урахуванням визначеного аксіоматичного ядра (рис. 1).

Теорія міжнародного руху капіталу обумовлюється наступними положеннями: вкладення капіталу триватиме до тих пір, поки прибутки від інвестування перевищуватимуть компенсацію за ризик, в тому числі за межі країни його походження (А. Сміт). Подальший розвиток теорії міжнародного руху капіталу дозволив довести, що притік іноземного капіталу відбувається у країнах, де існує його дефіцит для забезпечення потреб секторів економіки, за умови його надлишку у країнах-власниках капіталу. Це й обумовило виникнення явища глобалізації. Вважаємо доцільним погодитися із Н. Рязановою, яка зазначає: «...для зарубіжних фінансових та фінансово-промислових груп інвестування коштів в економіки країн із ринками, що формуються, є вигідною формою вкладень. 


\begin{tabular}{|c|c|}
\hline $\begin{array}{c}\text { Аксіоматичні ознаки конкуренції: } \\
\text { змагальність, суперництво суб'єктів } \\
\text { конкурентної взаємодії; } \\
\text { мотив, зацікавленість в досягненні } \\
\text { результату суб'єктів підприємництва }\end{array}$ & $\begin{array}{c}\text { Аксіоматичне ядро конкуренції: } \\
\text { вмотивовані дії суб’єктів підприємництва на } \\
\text { конкурентному ринку у оперуванні ціною } \\
\text { товару/послуги, якістю, інноваціями з метою } \\
\text { перемоги у конкурентній боротьбі }\end{array}$ \\
\hline еорії конкуренц & Особливості банківськ \\
\hline $\begin{array}{l}\text { Постулати розвитку банківського } \\
\text { конкуренція передбачає «змагання» } \\
\text { виживання сильніших гравців та вихід з ри } \\
\text { через недотримання макропруденційних } \\
\text { капіталу; } \\
\text { конкуренція змушує робити банківські } \\
\text { (для позичальників - за більш низькою ста } \\
\text { високою ставкою за депозитами, для вө }\end{array}$ & $\begin{array}{l}\text { ктору з позицій теорії конкуренцї̈: } \\
\text { нківських установ, результатом чого є } \\
\text { у банківських послуг слабких, в тому числі } \\
\text { ког, незалежно від джерел походження іх } \\
\text { ослуги більш привабливими для клієнтів } \\
\text { ою за кредитами, для вкладників - за більш } \\
\text { клієнтів - за різноманітністю переліку } \\
\text { ї установи тощо). }\end{array}$ \\
\hline
\end{tabular}

Рис. 1. Обгрунтування постулатів розвитку банківського сектору з позицій поведінкового підходу до теорії конкуренції

Незважаючи на ризики, що супроводжують іноземні інвестиції в цих країнах, у них існує дуже великий попит на фінансові ресурси, який обумовлює високу дохідність інвестицій. Зарубіжні інвестори мають можливість отримувати хороші прибутки, використовуючи західний досвід управління вкладеними коштами» [10, с. 68]. Відповідно, вважаємо аксіоматичним твердження, що обсяг входу іноземного капіталу у вітчизняний банківський сектор визначається внутрішнім попитом приймаючої країни.

Отже, витоки теорії міжнародного руху капіталу дозволили сформувати такі постулати розвитку банківського сектору (рис. 2).

Гіпотези методології дослідження розвитку банківського сектору в умовах конкурентної інтерналізації, які потребують підтвердження або спростування в результаті дослідження, є такими.

Гіпотеза підвищення обачності - посилення міжнародної конкуренції у банківській сфері потребує від приймаючої країни підвищення вимог до обачності (макропруденційні вимоги), і це $є$ своєрідним інструментом, через який відбувається регулювання надійності банківського сектору. Дана гіпотеза знаходиться в межах функціонального підходу теорій конкуренції, тобто має пояснити вплив конкуренції з боку іноземних банків та банків 3 іноземним капіталом на екстерналії для вітчизняного банківського сектору. Банківський сектор повністю відрізняється від інших секторів економіки завдяки своїм специфічним функціям, які роблять його об'єктом жорсткого регулювання, нагляду та публічного втручання. Світовою практикою визнано, що більш жорстке регулювання у вигляді макропруденційних вимог призводить до зниження рівня ризику банків, адже банки вразливі до нестабільності через свої особливі функції у фінансовій системі. 


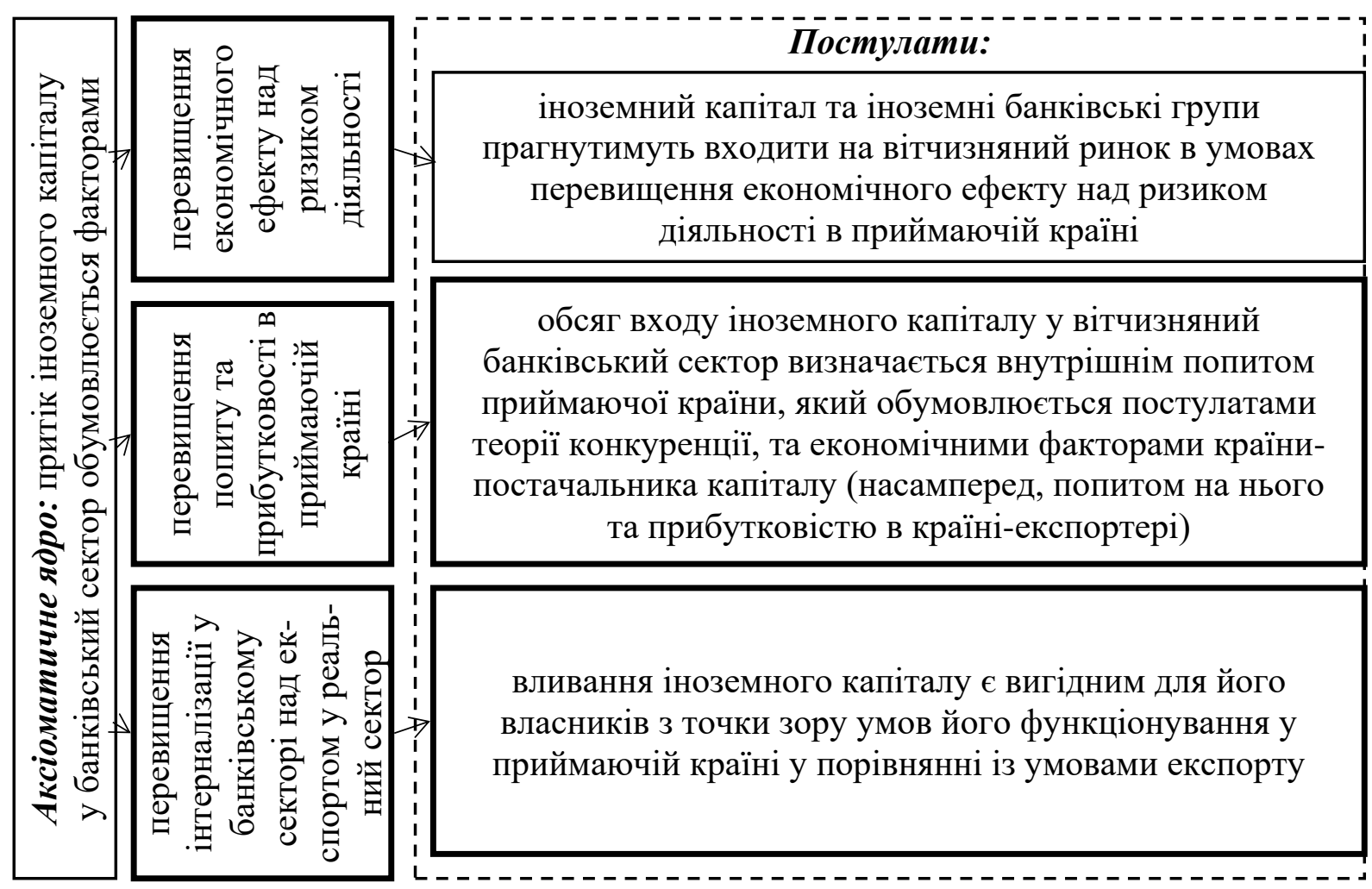

Рис. 2. Обгрунтування постулатів розвитку банківського сектору з позицій теорії міжнародного руху капіталу

О. Щуревич вказує на наступні напрями влосконалення макропруденційного регулювання за умов присутності іноземних банків та банків із іноземним капіталом: «вплив банків 3 іноземним капіталом на вітчизняний банківський сектор не можна однозначно оцінити як позитивний чи негативний, тому необхідно регулювати процедуру входження іноземних інвестицій у банківську систему для отримання максимальних переваг та мінімізації загроз функціонуванню вітчизняних банків. Необхідно здійснювати відстеження країн походження капіталу та режими регулювання і нагляду в них, перевіряти цілі та мотиви входження в український банківський сектор таких банків, аналізувати фінансові показники материнських банків для зменшення експорту фінансових ризиків, запровадити вимогу щодо надання стратегічного бізнес-плану хоча б на 5 років, а також, враховуючи суттєвий ризик інсайдерського кредитування у їхній діяльності, можливим $є$ встановлення підвищеного нормативу Н9 для цих банків» [11, с. 5].

Однак, однобічне посилення макропруденійних вимог тільки для іноземних банків може замаскувати важливі факти, особливо коли така політика впливає на різні за джерелом походження капіталу банківські установи в протилежних напрямках. Підвищення ж макропруденційних вимог до вітчизняних банків дозволить забезпечити ретельний контроль з боку держави, зменшити фінансову вразливість вітчизняного банківського сектору.

Наступна висунута гіпотеза переваг іноземних гравців знаходиться в межах структурного підходу до теорій конкуренції: більш слабкі внутрішні гравці є менш конкурентоспроможними, тому міжнародні банки інтерналізують негативні зовнішні ефекти за рахунок місцевих. Міжнародні ринки є більш 
ризикованими через безліч факторів, одним з яких є місцеві ринкові сили, такі як культура, регуляторна складність, економічна та політична нестабільність. Проте, отримання зовнішніх негативних ефектів також $є$ менш вразливим для іноземних банків: ці ефекти перекладаються 3 міжнародних на внутрішні банки або трансформуються в інші негативні ефекти для внутрішніх банків, або, за інших рівних умов, міжнародні банки за рахунок більшої фінансової спроможності можуть компенсувати вплив цих негативних ефектів і вчасно позбутися ризиків шляхом виведення капіталу. Відповідно, іноземні банківські групи та банки з іноземним капіталом гіпотетично мають низку конкурентних переваг. Для доведення цієї гіпотези має бути сформований методичний підхід до оцінки конкурентних умов на вітчизняному ринку банківських послуг.

3 цієї гіпотези, що має довести вплив структури банківського сектору за джерелами походження капіталу на розвиток банківського сектору, витікає гіпотеза диверсифікації: вихід з банківського сектору слабких гравців (іноземних або внутрішніх) нівелює або знижує загрози для економічної безпеки та фінансової стійкості приймаючої країни та іiі банківського сектору, зокрема через обмеження відтоку капіталу, диверсифікованого за джерелами походження, в період шоків для національної економіки. Означена гіпотеза має бути доведена в межах функціонального підходу.

Так, коли значна частина фінансової системи має проблеми, це може призвести до системного ризику, що спричиняє крихкість у всій економіці через центральну функцію вітчизняних фінансових установ. 3 іншого боку, відсутність кризи у фінансовій системі країни-постачальника банківського капіталу дозволяє іноземним банками продовжувати фінансування економіки приймаючої країни через банківський сектор, сприяючи подоланню шокового стану та нівелюючи загрози поглиблення кризи. Міжнародні банки з країн з розвиненою економікою, як правило, беруть на себе нижчий рівень ризику, а отже, мають більш високий рівень фінансової стабільності та надійності. Більше того, іноземні банки стягують низьку процентну маржу у приймаючих економіках, що змушує їх отримувати більше прибутку та працювати краще, ніж внутрішні банківські установи. У період банківських дефолтів та криз у різних країнах міркування щодо ефективності та конкуренції переважали проблеми фінансової стабільності [12], що може викликати певний ризикований стан окремих іноземних банків. Крім того, банківська конкуренція на внутрішньому ринку загрожує фінансовій стабільності через те, що вона спонукає вітчизняні банки брати на себе нові ризики. Отже доведення гіпотези має грунтуватися на методичному підході до оцінки економічної безпеки та фінансової стійкості банківського сектору в умовах конкурентної інтерналізації.

Наступна висунута гіпотеза - це гіпотеза розвитку банківського сектору відновлення довіри до банківської системи через присутність більш надійних за макропруденційними індикаторами, конкурентоспроможних та фінансово стійких іноземних банків або потужних вітчизняних, які вибороли право на існування у конкурентній боротьбі на ринку банківських послуг із іноземними, сприяє розвитку внутрішнього банківського сектору, набуттю ознак конкурентоспроможності вітчизняними банківськими установами та формуванню в них потенціалу виходу на міжнародний рівень. 
Дана гіпотеза полягає в межах використання комплексного підходу, до складу якого входять поведінковий, структурний та функціональний підходи. Доведення гіпотези має грунтуватися на емпіричних фактах стосовно того, в якій мірі та в яких напрямах присутність іноземних банків призводить до розвитку банківського сектору: збільшення його обсягу, розширення банківських послуг, диверсифікація ризику, укріплення внутрішніх банків за фінансовою стабільністю, збільшення питомої ваги на світовому фінансовому ринку.

Доведення даних гіпотез потребує розробки низки науково-методичних підходів (рис. 3).

\begin{tabular}{|c|c|c|}
\hline \multicolumn{3}{|c|}{ Теорї конкурентної інтерналізації } \\
\hline Теорія конкуренції & Теорія конкурентних переваг & Теорія міжнародного капіталу \\
\hline $\begin{array}{l}\text { Постулати розви } \\
\text { конкуренція перед } \\
\text { виживання сильніши } \\
\text { через недотримання } \\
\text { капіталу; } \\
\text { конкуренція змушу } \\
\text { іноземний капітал } \\
\text { ринок в умовах п } \\
\text { приймаючій країні; } \\
\text { обсяг входу інозел } \\
\text { внутрішнім попитом } \\
\text { вливання іноземног } \\
\text { функціонування у пр }\end{array}$ & $\begin{array}{l}\text { ку банківського сектору в умов } \\
\text { ачає «змагання» банківських } \\
\text { гравців та вихід з ринку банків } \\
\text { лакропруденційних вимог, нез } \\
\text { робити банківські послуги біль } \\
\text { іноземні банківські групи пра } \\
\text { ревищення економічного еф } \\
\text { ного капіталу у вітчизняний } \\
\text { риймаючої країни; } \\
\text { капіталу є вигідним для його } \\
\text { ймаючій країні у порівнянні із у }\end{array}$ & $\begin{array}{l}\text { конкурентної інтерналізації: } \\
\text { установ, результатом чого } \\
\text { ких послуг слабких, в тому числі } \\
\text { жно від джерел походження іх } \\
\text { привабливими для клієнтів; } \\
\text { утимуть входити на вітчизняний } \\
\text { гу над ризиком діяльності в } \\
\text { внівський сектор визначається } \\
\text { гасників з точки зору умов його } \\
\text { овами експорту. }\end{array}$ \\
\hline
\end{tabular}

\begin{tabular}{|c|c|c|c|}
\hline \multicolumn{3}{|c|}{ Гіпотези розвитку банківського сектору в умовах конкурентної інтерналізацї: } \\
\hline $\begin{array}{c}\text { гіпотеза підвищення } \\
\text { обачності }\end{array}$ & гіпотеза переваг \\
іноземних гравців & диверсифікації & біпотеза \\
\hline & $\downarrow$ & біпотеза розвитку \\
\hline
\end{tabular}

\begin{tabular}{|c|c|c|c|}
\hline \multicolumn{4}{|c|}{ Методичний рівень доведення гіпотез } \\
\hline $\begin{array}{c}\text { науковий підхід до } \\
\text { макропруденційного } \\
\text { регулювання в } \\
\text { умовах } \\
\text { конкурентної } \\
\text { інтерналізації }\end{array}$ & $\begin{array}{c}\text { методичний підхід } \\
\text { до оцінювання умов } \\
\text { конкурентної } \\
\text { інтерналізації в } \\
\text { банківському } \\
\text { секторі }\end{array}$ & $\begin{array}{c}\text { науково-методичний } \\
\text { підхід до оцінюван- } \\
\text { ня економічної } \\
\text { безпеки та фінансо- } \\
\text { вої стійкості бан- } \\
\text { ківського сектору }\end{array}$ & $\begin{array}{c}\text { методичний підхід до } \\
\text { оцінки розвитку } \\
\text { банківського сектору } \\
\text { в умовах } \\
\text { конкурентної } \\
\text { інтерналізації }\end{array}$ \\
\hline \multicolumn{4}{|c|}{ Очікувані результати дослідження } \\
\hline \multicolumn{2}{|c|}{$\begin{array}{c}\text { Формування напрямів трансформації } \\
\text { механізму розвитку банківського сектору } \\
\text { в умовах конкурентної інтерналізації }\end{array}$} & \multicolumn{2}{|c|}{$\begin{array}{c}\text { Обгрунтування структурних елементів } \\
\text { Стратегії як інструменту механізму } \\
\text { розвитку банківського сектору України }\end{array}$} \\
\hline
\end{tabular}

Рис. 3. Методологічний підхід до дослідження розвитку банківського сектору в умовах конкурентної інтерналізації 
Висновки $i$ перспективи подальших досліджень. Сформований методологічний підхід до дослідження розвитку банківського сектору в умовах конкурентної інтерналізації включає постулати розвитку банківського сектору в умовах конкурентної інтерналізації, гіпотези: підвищення обачності у макропруденційному регулюванні; переваг іноземних гравців у конкурентній боротьбі на приймаючому ринку банківських послуг; диверсифікації ризику щодо зниження загроз економічній безпеці та фінансовій стійкості банківського сектору; розвитку банківського сектору на основі відновлення довіри через присутність більш надійних іноземних банків або потужних вітчизняних. У результаті розроблення цих підходів має бути сформовано аналітичне забезпечення, яке стане підгрунтям при формуванні механізму та стратегії розвитку банківського сектору в умовах конкурентної інтерналізації.

\section{Лimepamypa:}

1. Дятлова Ю. В. Концепція конкурентної інтерналізації в банківському секторі: еволюція теорій і наукові положення. Проблеми і перспективи економіки та управління. 2019. № 1 (17). С. 219-227.

2. Дятлова Ю. В. Розвиток банківського сектору України: теорія, методологія, практика: монографія. Харків: Видавництво «НТМТ», 2019. 371 с.

3. Дятлова Ю. В. Конкурентоспроможність банківської системи: наукові погляди та практична реалізація. Фінансові дослідження: електронне наукове фахове видання. 2018. № 2. URL: https://fr.stu.cn.ua/index.pl?task= contextview\&l=ua\&id $=15$.

4. Смит А. Исследование о природе и причинах богатства народов. Москва: Эксмо, 2016. 1056 с.

5. Портер М. Конкурентное преимущество. Как достичь высокого результата и обеспечить его устойчивость. Москва: Альпина Паблишер, 2016. $716 \mathrm{c}$.

6. Caves R. E. Multinational Enterprise and Economic Analysis. Cambridge: University Press, 2007. 402 p.

7. Юрчишина Л. І. Аналіз концептуальних підходів до розуміння природи конкуренції та конкурентоспроможності. Інвестищіï: практика та досвід. 2011. №18. С. 41-47.

8. Литвиненко Т. Базові складові поняття «конкуренція». Вісник Київського національного університету імені Тараса Шевченка. Економіка. 2008. Вип. 99-100. С. 72-75.

9. Іванов Ю. Б. Орлов П. А., Іванова О. Ю. Конкурентні переваги підприємства: оцінка, формування та розвиток: монографія. Харків: ІНЖЕК, 2008. 352 с.

10. Рязанова Н. Еволюція теорії та практики вивозу капіталу та його особливості у контексті світової кризи початку XXI ст. Вісник Київського національного торговельно-економічного університету. 2010. № 2. С. 65-77.

11. Щуревич О. І. Система банківського регулювання та нагляду в умовах відкритої економіки України: дис. ... канд. екон. наук: 08.00.08 / Львівський національний університет імені Івана Франка. Львів, 2017. 250 с.

12. Vives X. Competition and stability in banking: The role of competition policy and regulation. Princeton: Princeton University Press, 2016. 344 p. 


\section{References:}

1. Djatlova Ju. V. Koncepcija konkurentnoji internalizaciji v bankivsjkomu sektori: evoljucija teorij i naukovi polozhennja. Problemy i perspektyvy ekonomiky ta upravlinnja. 2019. \# 1 (17). S. 219-227.

2. Djatlova Ju. V. Rozvytok bankivsjkogho sektoru Ukrajiny: teorija, metodologhija, praktyka: monoghrafija. Kharkiv: Vydavnyctvo «NTMT», 2019. 371 s.

3. Djatlova Ju. V. Konkurentospromozhnistj bankivsjkoji systemy: naukovi poghljady ta praktychna realizacija. Finansovi doslidzhennja: elektronne naukove fakhove vydannja. 2018. \# 2. URL: https://fr.stu.cn.ua/index.pl?task=contextview\&l=u a\&id=15.

4. Smit A. Issledovanie o prirode i prichinah bogatstva narodov. Moskva: Jeksmo, 2016. $1056 \mathrm{~s}$.

5. Porter M. Konkurentnoe preimushhestvo. Kak dostich' vysokogo rezul'tata i obespechit' ego ustojchivost'. Moskva: Al'pina Pablisher, 2016. 716 s.

6. Caves R. E. Multinational Enterprise and Economic Analysis. Cambridge: University Press, 2007. 402 p.

7. Jurchyshyna L. I. Analiz konceptualjnykh pidkhodiv do rozuminnja pryrody konkurenciji ta konkurentospromozhnosti. Investyciji: praktyka ta dosvid. 2011. \#18. S. 41-47.

8. Lytvynenko T. Bazovi skladovi ponjattja «konkurencija». Visnyk Kyjivsjkogho nacionaljnogho universytetu imeni Tarasa Shevchenka. Ekonomika. 2008. Vyp. 99-100. S. 72-75.

9. Ivanov Ju. B. Orlov P. A., Ivanova O. Ju. Konkurentni perevaghy pidpryjemstva: ocinka, formuvannja ta rozvytok: monoghrafija. Kharkiv: INZhEK, 2008. $352 \mathrm{~s}$.

10. Rjazanova N. Evoljucija teoriji ta praktyky vyvozu kapitalu ta jogho osoblyvosti u konteksti svitovoji kryzy pochatku KhKhI st. Visnyk Kyjivsjkogho nacionaljnogho torghoveljno-ekonomichnogho universytetu. 2010. \# 2. S. 65-77.

11. Shhurevych O. I. Systema bankivsjkogho reghuljuvannja ta naghljadu v umovakh vidkrytoji ekonomiky Ukrajiny: dys. ... kand. ekon. nauk: 08.00.08 / Ljvivsjkyj nacionaljnyj universytet imeni Ivana Franka. Ljviv, 2017. $250 \mathrm{~s}$.

12. Vives X. Competition and stability in banking: The role of competition policy and regulation. Princeton: Princeton University Press, 2016. 344 p.

Strengthening globalization and internalization requires a certain methodological basis for studying the development of the country's banking sector. The concept of competitive internalization in the banking sector was initiated due to certain factors (an increase in the share of the foreign banks number and assets in the banking market of countries with developing economies) and reasons (liberalization of access to the financial market of foreign banks).

The theoretical approach to the development of the banking sector in the context of competitive internalization has been based on the theory of competition, competitive advantages, and international capital movement. Scientific approaches to the study of developmental processes (behavioral, structural, functional, complex) have been determined. 
From the standpoint of these theories, the postulates of the development of the banking sector in terms of competitive internalization have been singled out:

the result of competition in the banking sector is the survival of stronger players and the exit from the banking market of weak players, including due to noncompliance with macro-prudential requirements, regardless of the sources of origin of their capital;

competition forces to make banking services more attractive for customers (for borrowers - at a lower interest rate on loans, for depositors - at a higher rate on deposits, for all customers - on the diversity of the list of banking products, the reliability of the banking institution, etc.);

foreign capital and foreign banking groups will seek to enter the domestic market in conditions of exceeding the economic effect over the risk of activity in the host country;

the volume of foreign capital entry into the domestic banking sector is determined by the domestic demand of the host country, which is stipulated by the postulates of competition theory, and economic factors of the capital supplier country (primarily demand for it and profitability in the exporting country);

the infusion of foreign capital is advantageous to its owners in terms of the conditions of its operation in the host country in comparison to the conditions of export.

Hypotheses of the banking sector development have been put forward:

increasing prudence in macro-prudential regulation (it is necessary to use a behavioral approach);

advantages of foreign players in the competition in the host market of banking services (it is necessary to use a structural approach);

diversification of risk to reduce threats to economic security and financial stability of the banking sector (it is necessary to use a functional approach);

development of the banking sector based on the restoration of confidence through the presence of more reliable foreign banks or powerful domestic banks (it is necessary to use an integrated approach).

As a result of the development of these approaches, analytical support should be formed, which will be the basis for the formation of the mechanism and strategy for the regulation of the banking sector in the context of competitive internalization. 